\title{
PELAKSANAAN TUGAS GURU DALAM MENINGKATKAN PRESTASI BELAJAR SISWA MELALUI BELAJAR KELOMPOK
}

\author{
Khoirul Anwar \\ alfasoy@yahoo.com \\ (Fakultas Agama Islam, Universitas Muhammadiyah Tangerang).
}

\begin{abstract}
Abstrak:
Permasalahan pokok dalam penelitian ini adalah bagaimana cara seorang guru dalam meningkatkan prestasi belajar siswa. Banyak cara dalam meningkatkan prestasi belajar siswa diantaranya adalah belajar kelompok. Belajar kelompok disini adalah belajar yang dilakukan oleh lebih dari satu orang dalam belajar berkelompok. Dengan belajar kelompok siswa dapat bekerja sama dan bertukar pikiran antara siswa yang satu dengan siswa yang lain. sehingga siswa yang lemah akan terbantu oleh siswa yang mempunyai kelebihan lebih dalam belajar. Prestasi belajar siswa adalah hasil yang dicapai siswa setelah melakukan kegiatan belajar mengajar. Dalam kegiatan belajar mengajar ini banyak sekali metode yang digunakan dalam meningkatkan prestasi belajar siswa. Pada penelitian ini metode yang digunakan adalah metode belajar kelompok.
\end{abstract}

\section{Kata Kunci:Prestasi Belajar, Belajar Kelompok}

\begin{abstract}
:
The main problem in this research is how a teacher can improve student achievement. There are many ways to improve student achievement, including group study. Group learning here is learning carried out by more than one person in group learning. By learning groups of students can work together and exchange ideas between one student and another. so that students who are weak will be helped by students who have more advantages in learning. Student learning achievement is the result achieved by students after carrying out teaching and learning activities. In teaching and learning activities, there are many methods used to improve student achievement. In this research, the method used is the group learning method.
\end{abstract}

Keywords: Learning Achievement, Group Learning.

\section{A. Pendahuluan}

Kompetisi dalam berbagai aspek kehidupan merupakan realitas yang tidak dapat dipungkiri, hal ini tidak hanya menjadi tantangan bahkan lebih merupakan tekanan apabila tidak disikapi dengan cermat, oleh karenanya semakin banyak orang sadar bahwa betapa penting peningkatan mutu sumber daya manusia melalui pendidikan. Human Development Resources (HDR) tidak hanya instrument tetapi merupakan sasaran pembangunan, pendidikan bukan sekedar sarana dasar tetapi kebutuhan dasar (basic need) untuk membangun, membentuk, membenahi dan mengembangkan bangsa menjadi bangsa yang kuat, berkualitas tinggi dan cerdas.

Masyarakat modern mulai menempatkan pendidikan sebagai komponen strategis (basic development) untuk meningkatkan sumber daya manusia, untuk itu pendidikan harus diorganisir dalam sebuah sistem supaya investasinya jelas, efektif dan terkendali.Upaya peningkatan mutu pendidikan menjadi salah satu prioritas pendidikan di 
Indonesia, khususnya pada jenjang pendidikan dasar dan menengah. Ahchmad Sanusi mengemukakan bahwa mutu pendidikan itu menyang kut soal mutu belajar, mutu mengajar, serta mutu bahan kajian dan pelajaran. Pendidikan adalah usaha sadar dan terencana untuk mewujudkan suasana belajar dan proses pembelajaran agar peserta didik secara aktif mengembangkan potensi dirinya untuk memiliki kekuatan spiritual keagamaan, pengendalian diri, kepribadian, kecerdasan, akhlak mulia, serta keterampilan yang diperlukan dirinya, masyrakat, bangsa dan Negara. ${ }^{1}$

Menurut Abin Syamsudin bahwa :"Pendidikan dapat mencakup seluruh proses hidup dan segenap bentuk interaksi individu dengan lingkungan baik secara formal, non formal dan informal, yang dalam perwujudan dengan tahapan tugas perkembangan secara optimis sehinga ia mencapai suatu tarap kedewasaan tertentu". Pendidikan yang dikemukakan di atas menunjukan bahwa pendidikan harus dilaksanakan sedini mungkin. Dalam proses ini timbul interaksi antara individu dengan lingkungan, baik lingkungan fisik maupun lingkungan social cultural. Pada hakekatnya proses belajar mengajar merupakan proses komunikasi antara guru dan siswa, dengan siswa sebagai komunikan, dan guru sebagai komunikator. Sedangkan menurut prinsif modern guru dan siswa itu sendiri sebagai komunikatornya. Jika sekelompok siswa menjadi komunikator terhadap siswa lainnya, maka guru bertindak sebagai pembimbing. Tindakan guru merupakan perangsang yang akan menimbulkan sikap kebiasaan tertentu pada siswa dalam kaitannya dengan belajar. Dari motif-motif belajar akan tumbuh sikap-sikap belajar

\footnotetext{
${ }^{1}$ Depdiknas RI, UU RI No. 20 Tahun 2003 Tentang Sistem Pendidikan Nasional, Jakarta: Depdiknas, 2003, h. 4.
}

tertentu yang akan turut menentukan aktivitas dalam belajar.

Dalam hal ini, M.Surya menjelaskan bahwa; "Sikap dan kebiasaan belajar merupakan manifestasi kemampuan siswa di dalam proses belajar mengajar, mempunyai peranan yang cukup berarti bagi pencapaian suatu prestasi belajar. Bagi berprestasi kurang, ternyata sikap dan kebiasaan belajarnya berintensitas rendah jika dibandingkan dengan temantemannya. Siswa yang berpotrensi tinggi yaitu siswa yang berprestasi lebih. Hal ini mengandung arti bahwa dengan potensi tinggi sekalipun, kalau sikap dan kebiasaan belajarnya kurang memadai, maka lebih besar kemungkinan untuk timbul gejala berprestasi kurang.

Dengan demikian salah satu factor yang menentukan dan sangat penting dalam pencapaian prestasi belajar siswa yaitu siswanya sendiri. Prestasi belajar siswa merupakan kemampuan dan keterampilan yang dimiliki para siswa setelah mengikuti pendidikan dan merupakan salah satu hal yang utama dari tujuan pendidikan. Faktor-faktor yang mempengaruhi belajar adalah: "factor siswa atau individu yang belajar, factor lingkungan, dan factor bahan atau materi yang dipelajari. ${ }^{2}$ Menurut Sumadi Suryabrata: ${ }^{3} \quad$ Faktor-faktor yang mempengaruhi belajar dapat dibedakan dua katagori yaitu factor ekstern dan factor Intern dengan perincian sebagai berikut:

1) Faktor ekstern terdiri dari: factor-faktor non social dan social

2) Faktor dalam diri (intern) terdiri dari: factor fisiologis dan psikologis.

Selanjutnya Amstrong menyatakan bahwa "Tingkat keberhasilan siswa tergantung kepada beberapa factor yaitu:

\footnotetext{
${ }^{2}$ Bimo Walgito, Bimbingan dan Penyuluhan di Sekolah, Jogjakarta: Andi Offset, 1989, h. 120

3 Sumadi Suryabrata, Metode Penelitian, Jakarta: Radja Grafindo Perkasa, 2004, h. 249
} 
kemampuan daya serap, tersedianya bukubuku pelajaran, lingkungan belajar dirumah dan disekolah yang kondusif untuk belajar dan tahap perhatian orang tua terhadap prestasi belajar siswa. ${ }^{4}$ Sedangkan Rooijaker mengemukakan adanya sejumlah factor yang mempengaruhi hasil belajar yaitu: factor yang berasal dari siswa itu sendiri dan factor yang berasal dari guru. ${ }^{5}$ Oleh karena itu faktor cara belajar siswa merupakan faktor yang ada dalam diri siswa untuk mencapai prestasi belajar yang baik. Banyak kegagalan siswa dalam belajar seperti drop out disebabkan oleh sikap dan cara belajar yang kurang baik dari siswa, perasaan tidak puas terhadap sekolah.

Situasi emosional yang terdapat dalam diri individu mempengaruhi dan mewarnai tingkah lakunya termasuk dalam belajar mengajar. Oleh karena itulah situasi emosional yang dialami oleh seseorang individu akan mempengaruhi hasil belajar yang dicapainya. Misalnya kesenangan, minat untuk belajar, sikap terhadap guru, gangguan pribadi. Semua merupakan karakteristik efektif yang harus diperhatikan dalam proses belajar.

\section{B. Fakta Dan Masalah}

Pembelajaran bidang studi IPA dengan menggunakan cara belajar kelompok diharapkan guru harus memiliki pemahaman yang proposional dan memahami proses cara belajar kelompok tersebut, sehingga dapat membantu kegiatan proses belajar mengajar. Oleh karena itu guru perlu memahami atau mengatahui keadaan sekarang dan keadaaan yang diinginkan.

\section{Keadaan Sekarang}

${ }^{4}$ David G. Amstrong, et al, Educational An Introduction. New York: Mac Millan Publishingco. Inc, 1981, h. 331

${ }^{5}$ Ad. Rooijakkers, Mengajar Dengan Sukses. Jakarta: Gramedia, 1989, h. 15
Cara belajar kelompok adalah cara belajar yang dilakukan siswa secara berkelompok. Cara belajar ini mengajarkan kepada siswa untuk berdiskusi antara satu kelompok dengan kelompok yang lainnya dalam memecahkan suatu permasalahan dengan dibimbing oleh guru bidang studi, dalam hal ini bidang studi IPA dan materinya adalah ekosistem. Siswa bebas untuk mengemukakan pendapatnya dan guru membimbing apabila ada siswa yang tidak sesuai dengan materi pelajaran yang disampaikan. Unsur-unsur pembelajaran kooperatif dengan cara belajar kelompok paling sedikit ada empat macam yakni :

a. Saling ketergantungan positif, artinya dalam pembelajaran kooperatif, dengan menggunakan belajar kelompok, guru menciptakan suasana yang mendorong agar siswa merasa saling membutuhkan antar sesama. Dengan saling membutuhkan antar sesama, maka mereka merasa saling ketergantungan satu sama lain dalam satu kelompok, bisa juga antar kelompok belajar.

b. Interaksi tatap muka, artinya menuntut para siswa dalam kelompok dapat saling bertatap muka sehingga mereka dapat melakukan dialog, tidak hanya dengan guru, tetapi juga dengan sesama siswa. Dengan interaksi tatap muka, memungkinkan para siswa dapat saling menjadi sumber belajar, sehingga sumber belajar menjadi variasi. Dengan interaksi ini diharapkan akan memudahkan dan membantu siswa dalam mempelajari suatu materi.

c. Akuntabilitas individual, artinya meskipun pembelajaran kooperatif menampilkan wujudnya dalam belajar kelompok, tetapi penilaian dalam rangka mengetahui tingkat penguasaan siswa terhadap suatu materi pelajaran dilakukan secara individual. Hasil penilaian secara individual tersebut 
selanjutnya disampaikan oleh guru kepada kelompok agar semua anggota kelompok mengetahui siapa anggota kelompok yang memerlukan bantuan dan siapa anggota kelompok yang dapat memberikan bantuan.

d. Keterampilan menjalin hubungan antar pribadi, artinya, melalui pembelajaran kooperatif akan menumbuhkan keterampilan menjalin hubungan antar pribadi. Hal ini dikarenakan dalam pembelajaran koopertif menekankan aspek-aspek: teggang rasa, sikap sopan terhadap teman, mengkritik ide dan bukan mengkritik orangnya, berani mempertahankan pikiran logis, tidak mendominasi orang lain, mandiri, dan berbagai sifat positif lainnya.

\section{Keadaan Yang Diinginkan}

Cara belajar kelompok dalam pembelajaran IPA baik di kelas atau di rumah mempunyai tujuan agar siswa mampu memahami tentang cara mengatur atau menyusun sesuatu. Dengan belajar kelompok perhatian siswa lebih terpusatkan pada pelajaran yang sedang diberikan, kesalahan-kesalahan yang terjadi bila pelajaran itu disampaikan oleh guru dapat diatasi melalui pengamatan dan contoh konkrit. Sehingga kesan yang diterima siswa lebih mendalam dan tinggal lebih lama pada jiwanya. Akibat selanjutnya memberikan motivasi yang kuat untuk siswa agar lebih giat belajar. Langkah-langkah belajar kelompok adalah:

a. Para siswa di dalam kelas dibagi menjadi beberapa kelompok, jadi ada 7 kelompok, masing-masing kelompok mempunyai anggota yang heterogen, baik jenis kelamin, ras, etnik, maupun kemampuannya (prestasinya)

b. Guru menyampaikan materi pelajaran

c. Lakukan dalam hal-hal yang bersifat praktis dan urgen dalam masyarakat d. Arahkan pendiskusian agar siswa dapat memperoleh pengertian yang lebih jelas, pembentukan sikap, serta kecakapan praktis

e. Usahakan supaya siswa dapat mengikuti diskusi

f. Selanjutnya masing - masing kelompok mempresentasikan kedepan kelas .

g. Selanjutnya tanggapan dari masing masing kelompok .

h. Selanjutnya guru memberikan tanggapan dan penegasan . dan tiap kelompok di beri skor atas penguasaannya terhadap materi pelajaran, dan kepada siswa secara individual atau kelompok yang meraih prestasi tinggi atau memperoleh skor sempurna di beri penghargaan .

i. Kesimpulan pelaksanaan cara belajar kelompok melalui tahapan sebagai berikuit :

1) penjelasan materi pembelajaran ;

2) dskusi atau kerja kelompok belajar

3) validasi oleh guru ;

4) evaluasi $\{$ tes $\}$;

5) menentukan nilai individu dan kelompok ;

6) penghargaan individu atau kelompok

\section{Pembahasan}

1. Analisis

Penelitian yang di lakukan berupa penelitian pengembangan model pembelajaran dan penelitian tindakan kelas Penelitian tindakan terikat dalam perencanaan dan pengimplementasikan perangkat pembelajaran bidang studi IPA melalui belajar kelompok. Tehnis analisis yang digunakan kualitatif, dengan pendekatan deskriftif kualitatif yang mendeskripsikan kegiatan siswa selama proses pembelajaran meliputi:

1. Setting Penelitian. 
Penelitian tindakan kelas ini di laksanakan di kelas 7.2 MTsN 3 Kota Tangerang, siswa di kelas ini berjumlah 37 orang, terdiri dari 17 siswa laki-laki dan 20 siswi perempuan, kemampuan akademik siswa - siswi di kelas ini rata - rata cukup . kondisi lain yang terikat bahwa latar belakang mereka cukup beragam, mereka terdiri dari beragam suku, sehingga secara keseluruhan kelas 7.2 relative cukup heterogen

\section{Data Dan Sumber Data}

Sesuai dengan fokus masalah yang di amati, maka data yang di perlukan dalam penelitian ini sebagai berikut:

a. hasil pengamatan terhadap langkah langkah dan kondisi pembelajaran

b. pemahaman materi bidang studi IPA oleh siswa Sedangkan sumber data dalam penelitian ini adalah guru dan siswa kelas 7.2 MTsN 3 Kota Tangerang tahun pelajaran 2019 2020.

3. Teknik Pengumpulan Data.

a. observasi dan catatan lapangan di gunakan untuk menjaring data yang berkaitan dengan peningkatan pemahaman materi pembelajaran.

b. evaluasi digunakan untuk menjaring data yang berkaitan dengan peningkatan hasil pemahaman materi pembelajaran.

4. Teknik Analisa Data.

Data berasal dari lembar observasi, antara lain yang di amati adalah: kerjasama dan kelompok, memberikan ide, mengajukan pertanyaan, memperhatikan pertanyaan teman, memberikan tanggapan, kemampuan memahami materi, partisipasi dalam kelompok, kemampuan menengahi jika ada kelompok yang salah paham, kemampuan menjelaskan dan menyimpukan materi yang di bahas.

5. Monitoring Pelaksanaan Tindakan.

Untuk memudahkan pelaksanaan tidakan kelas dikelas, maka penelitian dibekali dengan lembar observasi kegiatan pembelajaran, agar pembelajaran berlangsung dengan baik dan lancer, dan penelitian memberikan arahan tentang cara pengisian lembar observasi kepada rekan guru yang membantu dalam penelitian tersebut. Dari hasil pemantauan secara kolaboratif didiskusikan. Pembahasan tersebut dititik beratkan. Dari hasil diskusi dijadikan bahan untuk membuat rencana berikutnya, dengan harapan agar pelaksanaan pada siklus berikutnya menjadi lebih baik.

6. Pengecekan Keabsahan Data.

Guru menjamin keabsahan data di lakukan dengan mengecek keabsahan data dengan mengkonfirmasikan data yang telah ada dengan data, sumber data dan ahli. Dalam penelitian ini di lakukan diskusi, membandingkan pendapat beberapa peneliti, hasil pengamatan, data evaluasi

7. Rancangan Penelitian.

Untuk menerapkan perangkat pembelajaran bidang studi IPA melalui cara belajar kelompok ini digunakan rancangan penelitian tindakan, selain itu juga memecahkan masalah-masalah praktis, juga untuk memperbaiki strategi pembelajaran. Dalam penelitian ini tindakan yang dimaksud penerapan pembelajaran bidang studi IPA melalui cara belajar kelompok untuk meningkatkan pemahaman siswa pada materi ekosistem. Penelitian tindakan kelas melalui 4 tahap yaitu: perencanaan, pelaksanaan tindakan, observasi, dan refleksi, yang dilasanakan dalam dua siklus (tiap siklus dilakukan 2 kali tatap muka).

Pada kegiatan siklus akan dilakukan sesuai dengan tahap-tahap tersebut.

Rencana tindakan siklus 1

1. Perencanaan

a. Peneliti melakukan analisis kurikulum untuk menentukan standar kompetensi dan kompetensi dasar yang akan 
disampaikan kepada siswa melalui proses belajar mengajar dengan cara belajar kelompok.

b. Membuat rencana proses belajar mengajar bidang studi IPA dengan cara belajar kelompok.

c. Membuat instrument yang digunakan dalam siklus penelitian tindakan kelas/alat Bantu/media yang diperlukan.

d. Membuat alat evakuasi.

Secara garis besar tahapan proses belajar mengajar bidang studi IPA dengan cara belajar kelompok adalah sebagai berikut:

a. Tahap Persiapan. Pada tahap ini, kegiatan yang dilakukan diantaranya mempersiapkan materi dan rancangan pembelajaran yang mengarah kepada cara belajar kelompok, membuat kriteria kelompok Heterogen (jenis kelamin dan kemampuan) dan mempersiapkan instrument observasi disertai cara penskoran.

b. Tahap Penyajian Materi Dengan Cara Belajar Kelompok. Dalam tahap ini pengajar menyebutkan tujuan pembelajaran memotivasi rasa ingin tahu, memberikan apersepsi, umpan balik sesering mungkin, penjelasan yang tepat terjadi miskonsepsi, dan beralih pada konsep lain, jika siswa telah memahami pokok masalahnya. Selanjutnya dilakukan diskusi antar siswa dan selanjutnya oleh guru atau orang lain atau bisa juga dipilih salah seorang siswa yang sangat menguasai tentang materinya.

c. Tahap kegiatan kelompok. Selanjutnya masing-masing kelompok membahas materi yang dibagikan, siswa mempelajari konsep-konsep materi ekosistem, dan mempresentasikan didepan kelas juga digunakan untuk melatih keterampilan kooperatif siswa dalam masing-masing kelompok. Jika salah satu siswa belum memahami materi melalui diskusi yang telah dilakukan, maka teman sekelompoknya bertanggung jawab untuk menjelaskan.

d. Tahap selanjutnya, tanggapan dari masing-masing kelompok. Selanjutnya guru memberikan tanggapan dan penjelasan tentang materi yang dijelaskan.

e. Tahap tes hasil belajar.

Dilakukan $1 \mathrm{x}$ tes setelah pertemuan, tes dikerjakan secara individu mandiri, tes uraian dikerjakan selama 45 menit. Hasil tes digunakan untuk mengetahui apakah ada peningkatan siswa pada pemahaman bidang studi IPA materi ekosistem.

2. Pelaksanaan. Kegiatan yang di lakukan dalam tahap ini adalah melaksanakan pembelajaran bidang studi IPA materi ekosistem dengan cara belajar kelompok yang telah di rencanakan .

3. Observasi Pada tahap ini di lakukan observasi terhadap pelaksanaan tindakan dengan menggunakan lembar observasi.

4. Refleksi. Hasil yang didapat dalam tahap observasi di kumpulkan serta di analisis. Pada tahap ini, pengajar dapat merefleksi diri berdasarkan hasil observasi dan diskusi. Untuk mengkaji apakah tindakan yang di lakukan dapat meningkatkan pemahaman siswa pada bidang studi IPA. Hasil analis data yang dilakukan dalam tahapan akan di pergunakan sebagai acuan untuk merencanakan siklus berikutnya, Data dan cara pengambilannya

a. sumber :sumber data dari tindakan kelas ini adalah siswa dan peneliti

b. jenis data: jenis data yang di dapatkan adalah data kuantitatif dan data kualitatif yang terdiri dari:

1. rencana pembelajaran

2. data hasil observasi terhadap pelaksanaan 
3. cara pengambilan data

pembelajaran
hasil belajar.

a. data hasil belajar: di proleh melalui pos tes dan pre tes data tentang situasi pembelajaran, di peroleh melalui lembar

b. observasi data tentang keterkaitan antara perencanaan dengan pelaksanaan di dapat dari rencana pembelajaran dan lembar observasi.

2. Indikator kinerja

Yang menjadi indikator keberhasilan tindakan kelas ini adalah jika terjadi perubahan peningkatan pemahaman siswa pada bidang studi IPA melalui cara belajar kelompok. Secara kuantitatif dapat di indikasikan jika 65\%. Dari seluruh siswa terlihat pemahaman terhadap bidang studi IPA berubah lebih baik. Hal ini diwujudkan dengan adanya kemampuan siswa $80 \%$ dalam menjawab soal uraian terstruktur dengan benar. Disamping itu juga $85 \%$ siswa terlibat aktif dalam pembelajaran bidang studi IPA melalui cara belajar kelompok.

a. Tahap Perencanaan. Pada tahap ini peneliti melakukan refleksi awal, merumuskan permasalahan dan merencanakan tindakan yang meliputi rancangan strategi dalam penyampaian dan pengelolahan pembelajaran IPA melalui cara belajar kelompok. Pada tahap ini juga dikembangkan strategi pembelajaran, instrument pengumpul data berupa lembar pengamatan perangkat tes hasil belajar serta menyusun rencana pengolahan data.

b. Tahap Pelaksanaan Tindakan. Pada tahap ini peneliti melaksanakan scenario tindakan yang telah direncanakan serta melakukan pengamatan selama kegiatan pembelajaran berlangsung sesuai dengan jadwal penelitian. Selama kegiatan pembelajaran berlangsung dilakukan pengamatan oleh tim dengan menggunakan instrument pengamatan, serta melakukan evaluasi dan refleksi. Selama pelaksanaan tindakan ditujukan untuk melakukan perbaikan-perbaikan dalam pembelajaran berikutnya.

1 Tindakan Siklus I

Siklus 1 pada penelitian dilaksanakan pada tanggal 22 Agustus 2019 sampai dengan 10 September 2019, dengan materi yang dibahas ekosistem. Tindakan yang dilakukan adalah pendekatan pembelajaran IPA melalui cara belajar kelompok dengan langkahlangkah sebagai berikut:

a. Guru menyajikan materi sesuai dengan rencana pembelajaran yang telah dibuat sebelumnya.

b. Guru mengelompokkan siswa yang anggota kelompok terdiri dari berbagai ragam (heterogen).

c. Guru membagikan lembar materi kepada masing-masing kelompok, dengan materi yang berbeda, agar dipahami oleh kelompok siswa tersebut.

d. Guru atau orang lain atau siswa sendiri mendiskusikan materi yang telah dijelaskan sebelumnya.

e. Tahap selanjutnya masing-masing kelompok mempresentasikan didepan kelas, guru memberi kesempatan untuk sekitar 10 menit.

f. Selanjutnya tanggapan dari berbagai kelompok.

g. Tahap selanjutnya guru memberi tanggapan dan penegasan

\section{Hasil tindakan}

a. Ketika guru mendiskusikan, seluruh siswa memperhatikan dengan seksama karena rasa ingin tahunya.

b. Ketika guru membagi anggota kelas dalam kelompok-kelompok kecil, terlihat siswa mulai menunjukan antusias dan rasa ingin 
tahu, mereka ada yang bertanyatanya apa yang akan dilakukan (ketika guru membagikan lembar materi kepada masing-masing kelompok yang berbeda)

c. Tampak pada awalnya, mereka masih lebih banyak yang diam dengan pikirannya masing-masing. Mereka masih ada yang malu, enggan untuk berbicara dengan teman satu kelompok.

d. Seiring berjalannya waktu, setelah kurang dari 20 menit tampak mereka sudah mulai berusaha untuk berinteraksi dengan teman satu kelompok.

e. Kelompok-kelompok siswa mulai melakukan pemahaman materi dengan selalu berdiskusi sesama teman satu kelompok. Tetapi masih ada kelompok yang masih belum serius, sering berbicara masalah lain.

Untuk memperbaiki kelemahan dan mempertahankan keberhasilan yang telah dicapai pada siklus I, maka pada pelaksanaan siklus kedua dapat dibuat perencanaan sebagai berikut:

a. Memberikan motivasi kepada kelompok siswa agar lebih aktif lagi dalam pembelajaran.

b. Guru lebih intensif membimbing kelompok siswa yang mengalami kesulitan dalam melaksanakan tata cara sholat lima waktu.

c. Memberikan pengharaan kepada siswa (reward).

2 Tindakan Siklus II

Siklus kedua dilaksanakan tanggal 20

September 2019 s.d 15 Oktober 2019 materi yang disajikan adalah ekosistem.

a. Guru memberikan motivasi kepada kelompok siswa agar lebih aktif lagi dalam pembelajaran IPA melalui cara belajar kelompok. b. Lebih intensif membimbing kelompok siswa yang mengalami kesulitan.

c. Memberikan panghargaan atau reward. Hasil tindakan

a. pada siklus II adanya suasana pembelajarran yang sudah mengarah kepada cara belajar kelompok. Siswa dalam satu kelompok menunjukkan saling membantu untuk memahami materi yang telah diberikan melalui diskusi, diskusi, tanya jawab, pokoknya sudah terjadi interaksi.

b. Siswa mulai tidak merasa canggung lagi saling bertukar pandapat, berbagai ide dengan teman.

c. Guru secara aktif memantau diskusi kerja kelompok, jika ada hal-hal yang kurang jelas, diberi kejelasan oleh guru. Terlihat semangat kebersamaan dalam proses pambalajaran.

d. Dari 7 kelompok yang ada, terlihat ada 4 kelompok yang paling menonjol, 4 kelompok dapat menyelesaikan tugas sesuai dengan waktu yang ditentukan, satu kelompok terlihat masih lamban.

e. Kelompok yang paling lamban menyelesaikan tugas terlihat kurang berinteraksi dengan satu sama lain, tampak mereka lebih banyak berdiam diri, sesekali saja berbicara.

f. Tanggapan siswa dikelas cukup baik, wakil kelompok yang tampol cukup baik dalm menerima masukan dari temannya.

g. Hasil tes formatif rata-rata adalah 75 ada 11 siswa (30\%). siswa yang dapat nilai $60-74$ ada 12 orang (32\%) yang dapat $79-100$ ada 14 orang (38\%)

h. Meningkatnya aktivitas siswa dalam PBM didukung oleh meningkatnya aktivitas guru meningkatnya suasana pembelajaran IPA melalui cara belajar kelompok, guru intensif membimbing siswa saat siswa mengalami kesulitan dalam PBM, dapat dilihat dari hasil observasi aktivitas guru dalam PBM 
meningkat dari $65 \%$ pada siklus pertama menjadi $85 \%$ pada siklus kedua.

Hasil observasi dan refleksi pada siklus II, yang perlu diperhatikan sebagai rencana tindakan pada siklus berikutnya adalah :

a. Masih ada siswa yang belum optimal telibat dalam proses interaksi dengan kelompoknya.

b. Masih ada siswa yang belum menguasai materi ekosistem

c. Siswa yang kemampuan akademik lebih tinggi agak lebih mendominasi aktivitas dalam kelompok

d. Hasil tes formatif (setelah menggunakan pembelajaran IPA melalui cara belajar kelompok mengalami peningkatan). Sebelum menggunakan pembelajaran IPA melalui cara belajar kelompok rata kelas hanya 75 setelah dilakukan pembelajaran IPA melalui cara belajar kelompok manjadi 80 siklus I, pada siklus II menjadi 90.

3. Pemecahan Masalah

Berdasarkan analisis di atas, maka alternative cara pemecahan masalah adalah sebagai berikut:

1. Untuk mengetahui ada tidaknya peningkatan pemahaman siswa pada bidang studi IPA melalui cara belajar kelompok dengan memperbaiki strategi pembelajaran yang dilakukan oleh guru.

2. Untuk mengetahui ada tidaknya hasil peningkatan siswa dalam pemahaman bidang studi IPA melalui cara belajar kelompok dengan melakukan observasi, lalu merancang evaluasi, situasi belajar dengan pembentukan kelompok-kelompok belajar.

3. Untuk mengetahui peningkatan hasil belajar siswa pada bidang studi IPA, maka guru bidang studi IPA harus menguasai berbagai macam metode mengajar dan memahami cara belajar siswanya.

\section{Kesimpulan}

Berdasarkan data, analisis data dan pembahasan tentang upaya yang dilakukan untuk meningkatkan pemahaman siswa melalui cara belajar kelompok pada bidang studi IPA dapat ditarik kesimpulannya sebagai berikut:

Kegiatan belajar mengajar bidang studi IPA melalui cara belajar kelompok ternyata efektif, karena dapat meningkatkan pemahaman siswa kelas 7.2 MTsN 3 Kota Tangerang tahun pelajaran 2019-2020 secara deskripsi diperoleh halhal sebagai berikut;

a. Dari hasil belajar siswa diperoleh 70 $\%$ (10 siswa dari 37 siswa) memperoleh skor nilai diatas rata-rata.

b. Rata-rata nilai ulangan pada siklus II naik sebesar $0,75 \%$ dibandingkan ratarata nilai ulangan siklus I.

c. Rata-rata nilai ulangan pada siklus III naik sebesar $1,20 \%$ dibandingkan dengan rata-rata nilai ulangin siklus II

d. Dari observasi dikelas, menunjukkan bahwa siswa yang berkemampuan tinggi terlihat lebih aktif dan antusias, sehingga memunculkan kerjasama serta mau berinteraksi, saling membantu serta berbagi pendapat, mau mendengarkan pendapat teman dalam menyelesaikan tugas. Dari 7 kelompok, $75 \%$ dapat menyelesaikan dengan baik dan sesuai dengan waktu yang telah ditentukan.

e. Melalui cara belajar kelompok pada pembelajaran bidang studi IPA, siswa melaksanakan sendiri dan membangun sendiri pengetahuan, menemukan langkah-langkah dalam mencari penyelesaian dari suatu materi yang harus dipahami dan dikuasai oleh siswa, baik secara individu maupun kelompok. 
f. Melalui cara belajar kelompok, pembelajaran bidang studi IPA lebih menyenangkan.

g. Kegiatan belajar mengajar bidang studi IPA melalui cara belajar kelompok dapat meningkatkan pemahaman dan aktivitas kegiatan belajar mengajar.

\section{DAFTAR PUSTAKA}

Ad. Rooijakkers, 1989, Mengajar Dengan Sukses. Jakarta: Gramedia.

David G. Amstrong, et al,198, Educational An Introduction. New York: Mac Millan Publishingco. Inc.

Depdiknas RI, 2003, UU RI No. 20 Tahun 2003 Tentang Sistem Pendidikan Nasional, Jakarta: Depdiknas
Pasaribu dan Simanjuntak. 1986. Didaktik dan Metodik. Bandung. Tarsito

Rostiyah N.K. 2005. Dasar-dasar Evaluasi Pendidikan. Yogyakarta. Bumi Aksara

Slameto. 1987. Belajar dan Faktor-faktor Yang Mempengaruhinya. Jakart Bina Aksara

Sumadi Suryabrata. 1983. Proses Belajar Mengajar di Perguruan Tinggi. Yogyakarta. Andi Offset

Sumadi Suryabrata, 2004 Metode Penelitian, Jakarta: Radja Grafindo Perkasa.

Walgito, Bimo, 1989, Bimbingan dan Penyuluhan di Sekolah, Jogjakarta: Andi Offset. 
Pelaksanaan Tugas Guru Dalam Meningkatkan Prestasi Belajar Siswa Melalui Belajar Kelompok 